\title{
KEPUTUSAN PEMBELIAN DITINJAU DARI ATMOSFER, KUALITAS PRODUK DAN BRAND IMAGE DI WARUNG APUNG PONDOK ROSO KLATEN
}

\author{
Laila Agusti Rachmawati, Burhanudin AY, Ratna Damayanti \\ Fakultas Ekonomi Universitas Islam Batik Surakarta \\ Email : laili.agusti@gmail.com
}

\begin{abstract}
Abstrak : Penelitian ini bertujuan menganalisis adanya pengaruh atmosfer, kualitas produk, dan brand image kepada keputusan pembelian konsumen di Warung Apung Pondok Roso Rowo Jombor Klaten. Penelitian ini merupakan penelitian kuantitatif. Semua konsumen di warung apung Rowo Jombor Klaten menjadi populasi dalam penelitian, sampel terambil 100 orang, dengan menggunakan non random sampling melalui purposive sampling. Data penelitan berupa kuesioner dengan skala Likert $1-5$, dan teknik analisis data memakai regresi linear berganda yang diolah dengan komputer program IBM SPSS 21. Hasil temuan yang didapat : Hasil uji $F$ didapat nilai sig. 0,000, sehingga disimpulkan bahwa keputusan pembelian dapat dipengaruhi oleh atmosfer, kualitas produk serta brand image secara bersamaan. Hasil uji $t$ diperoleh sig. 0,011, sehingga atmosfer secara individual berpengaruh secara signifikan kepada keputusan pembelian konsumen. Dari uji t didapat nilai sig. 0,009, sehingga kualitas produk secara individual secara signifikan mempengaruhi keputusan pembelian konsumen. Dari hasil uji $t$ didapat nilai sig. 0,000, sehingga brand image secara individual mempengaruhi keputusan pembelian konsumen. Model regresi diperoleh nilai koefisien regresi positif, sehingga disimpulkan jika atmosfer, kualitas produk serta brand image ditinggatkan maka akan meningkatkan keputusan pembelian konsumen. Dari uji koefisien determinasi diperoleh nilai Adjusted $R$ Square sebesar 0,409, maka diperoleh kesimpulan kemampuan di dalam variabel atmosfer, kualitas produk serta brand image mempengaruhi variable keputusan pembelian sebesar 40,9\% sisanya 50,1\% dari variabel lain yang tidak digunakan dalam penelitan ini.
\end{abstract}

Kata kunci : Atmosfer, Kualitas Produk, Brand Image, Keputusan Pembelian.

Abstract : The research are aimed at analyzing the influence of the atmosphere, product quality, and brand image on consumer purchasing decisions at Pondok Roso Rowo Jombor Klaten floating shop. This research is a quantitative research. All consumers in the Rowo Jombor Klaten floating shop became the population in the study, the sample was taken by 100 people, using non random sampling through purposive sampling. Research data in the form of questionnaires with a Likert scale of 1 - 5, and data analysis techniques using multiple linear regression assisted with IBM SPSS 21 computer program. Findings obtained: F test results obtained sig. 0,000, thus concluded the atmosphere, product quality and brand image simultaneously have a significant effect on consumer purchasing decisions. T test results obtained sig. 0.011, it is concluded that the individual atmosphere significantly influences consumer purchasing decisions. From the t test obtained sig. 0.009, it was concluded that the quality of the individual products significantly influence consumer purchasing decisions. From the t test results obtained sig. 0,000, it is concluded that brand image has an individual effect on consumer purchasing decisions. Regression models obtained positive regression coefficient 
values, so it was concluded that if the atmosphere, product quality and brand image were raised it would increase consumer purchasing decisions. From the coefficient of determination test obtained Adjusted $R$ Square value of 0.409, the conclusion is the ability in the atmospheric variables, product quality and brand image affect the purchase decision variable by $40.9 \%$ the remaining $50.1 \%$ is influenced by other variables not used in this research .

Keywords: Atmosphere, Product Quality, Brand Image, Purchasing Decisions.

\section{PENDAHULUAN}

Situasi yang saat ini semakin modern menjadikan konsumen lebih selektif dalam memilih, pada suatu tempat makan harus memperhatikan atmosfer warungnya. Sebagian besar orang memilih untuk memenuhi kebutuhan makannya di rumah makan. karena tidak banyak membuang waktu untuk memasak. Selain dapat memilih menu makanan sesuai yang diingikan bagi orang yang bekerja ataupun pelajar ingin mencari tempat makan yang suasananya nyaman serta menarik.

Warung makan harus memiliki daya tarik tersendiri yang lain daripada yang lainnya. Warung makan memiliki berbagai ciri khas tersendiri mulai dari variasi menu masakan yang ditawarkan hingga tempat makan yang unik sehingga menjadikan daya tarik konsumen tersendiri. Atmosfer warung makan, kualitas produk yang ditawarkan serta brand image dari warung makan merupakan faktor yang dipikirkan konsumen dalam melakukan suatu pembelian. Keputusan pembelian yaitu melakukan suatu proses dimana seseorang akan menentukan suatu tindakan pembelian, untuk mengurangi resiko yang terjadi sesorang akan melakukan pemilihan dan pertimbangan yang matang (Margaretha dan Edwin , 2012 ).

Warung apung Pondok Roso Rowo Jombor Klaten juga mengutamakan atmosfer, kualitas produk serta brand image untuk menghadapi persaingan dalam bisnis rumah makan. Namun dalam penerapan kualitas - kualitas tersebut terdapat pengaruh apabila diterapkan pada warung apung Pondok Roso Rowo Jombor Klaten yang saat ini sedang berupaya lebih maju lagi. Hal tersebut dilakukan guna untuk menghadapi persaingan bisnis kuliner yang sangat ketat.

\section{TINJAUAN TEORI}

\section{Keputusan Pembelian}

Semakin ketatnya persaingan warung makan yang ada, maka semakin banyak pula hal hal yang perlu dipertimbangkan dalam melakukan keputusan pembelian. Menurut Philip Kotler (2007, p.223) Keputusan Pembelian yaitu : suatu proses secara bertahap yang dilakukan oleh seseorang sebelum melakukan pembelian suatu barang atau jasa. Menurut Shciffman dkk (2004, p.289) mengungkapkan bahwa keputusan pembelian konsumen adalah tindakan - tindakan yang dilakukan oleh seseorang untuk memilih alternatif.

\section{Atmosfer}

Kotler \& Keller ( 2009, p.61 ) atmosfer yaitu "desain lingkungan dengan menggukanan komunikasi visual, penerangan, alunan musik, aroma serta pemilihan warna untuk menarik respon emosional dan persepsi konsumen. Sedangkan Utami ( 2010, p.193 ), menyatakan 
"Suasana cafe ( atmosfer) adalah desain ruang lingkup menggunakan komunikasi visual, penerangan ruangan, pemilihan warna dekorasi, alunan lagu, dan aroma dalam ruangan untuk merancang respon emosional dan persepsi konsumen dalam melakukan suatu pembelian.

\section{Kualitas Produk}

Kotler, (2002, p.268) mengatakan bahwa produk adalah suatu barang atau jasa yang dijual kepada konsumen di suatu pasar untuk memenuhi keinginan dan kebutuhan.

\section{Brand Image}

Keller (1993, p.3), menyatakan bahwa brand image adalah penilaian atau persepsi konsumen terhadap sebuah merk yang disampaikan melalui asosiasi merk yang ada di dalam benak konsumen . Asosiasi merk menurut Aaker (1991, p.109) adalah sesuatu yang berhubungan dengan ingatan dan pemikiran seseorang mengenai merk.

\section{Kerangka Pemikiran}

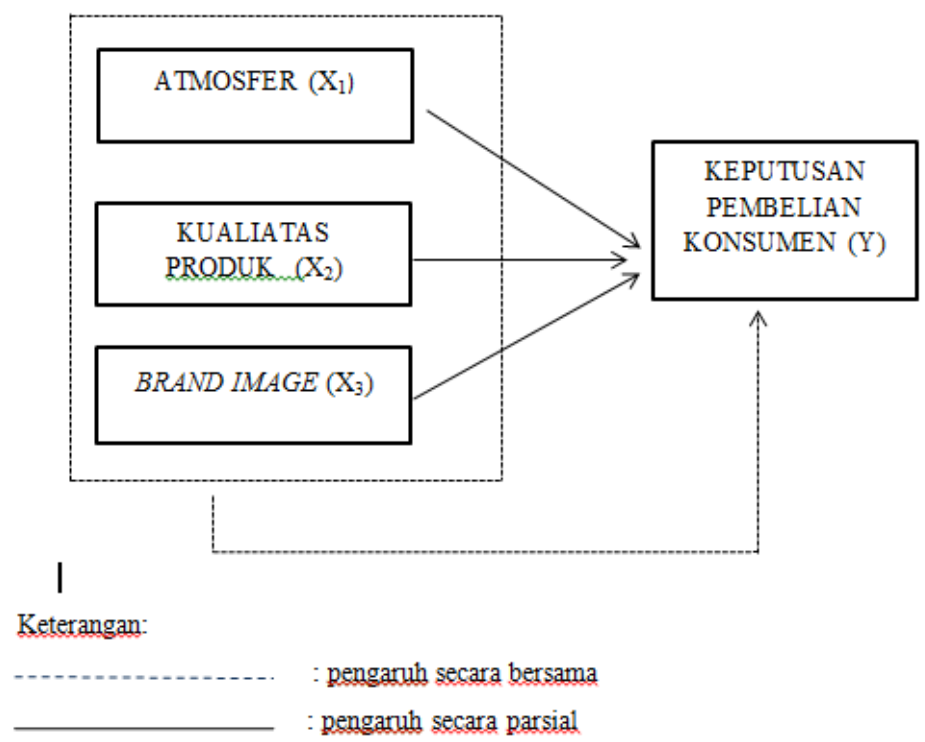

\section{Hipotesis}

1) Diduga atmosfer, kualitas produk, dan brand image secara bersama-sama mempengaruhi keputusan pembelian konsumen secara signifikan di warung apung Pondok Roso Klaten.

2) Diduga atmosfer mempengaruhi secara positif dan signifikan terhadap keputusan pembelian konsumen di warung apung Pondok Roso Klaten.

3) Diduga kualitas produk mempengaruhi keputusan pembelian konsumen dengan pengaruh positif dan signifikan di warung apung Pondok Roso Klaten.

4) Diduga brand image produk mempengaruhi keputusan pembelian konsumen dengan pengaruh positif dan signifikan di warung apung Pondok Roso Klaten. 


\section{METODE PENELITIAN}

Penelitian ini dilakukan dengan cara pendekatan kuantitatif. Semua konsumen Pondok Roso Rowo Jombor Klaten menjadi populasi penelitian serta sampel yang terambil 100 konsumen, dengan teknik non random sampling ini menggunakan kuesioner penelitian skala Likert $1-5$, dan dianalisis memakai regresi linear berganda serta diolah menggunakan komputer program IMB SPSS Statistics 21.

\section{HASIL DAN PEMBAHASAN}

Analisis Data

\section{Koefisien Determinasi}

Tabel 1. Hasil Uji Koefisien Determinasi

\begin{tabular}{cccc}
\hline$R$ & R Square & $\begin{array}{c}\text { Adjusted } \mathrm{R} \\
\text { Square }\end{array}$ & \multicolumn{1}{c}{ Keterangan } \\
\hline 0,654 & 0,427 & 0,409 & $\begin{array}{l}\text { Variasi variabel atmosfer, kualias produk, } \\
\text { dan brand image terhadap kepuasan } \\
\text { konsumen sebesar 40,9\% }\end{array}$ \\
\hline
\end{tabular}

Berdasakan tabel 1 di atas muncul nilai $R$ Square sebesar 0,427, sedangkan nilai Adjusted $R$ Square 0,409, sehingga dapat disimpulkan kemampuan variabel atmosfer, kualitas produk, serta brand image menerangkan variasi variabel keputusan pembelian sebesar 0,409 atau 40,9\%, sedangkan 59,1\% lainnya merupakan pengaruh dari variabel yang tidak dilakukan dalam penelitian ini.

\section{Analisis Regresi Linear Berganda}

Tabel 2. Hasil Analisis Linear Berganda

\begin{tabular}{lcccc}
\hline \multicolumn{1}{c}{ Variabel } & $\rho$ & thitumg $_{\text {non }}$ & Sig. & Keterangan \\
\hline Konstanta & 3,250 & 1,229 & 0,222 & \\
Atmosfer & 0,274 & 2,581 & 0,011 & Pengaruh positif \\
Kualitas Produk & 0,238 & 2,679 & 0,009 & Pengaruh positif \\
Brand Image & 0,300 & 3,763 & 0,000 & Pengaruh positif \\
\hline
\end{tabular}

Berdasarkan hasil tersebut sehingga dapat disusun persamaan regresi di bawah ini : $\mathrm{Y}=3,250+0,274 \mathrm{X} 1+0,238 \mathrm{X} 2+0,366 \mathrm{X} 3+\mathrm{e}$ Interpretasi:

1. $\mathrm{a}=$ Nilai konstanta, diperoleh nilai sebesar 3,250 jadi kesimpulan yang dapat diambil yaitu keputusan pembelian sebesar 3,250 dengan catatan tidak menggunakan variabel atmosfer, kualitas produk, dan brand image.

2. b1 = Nilai koefisien regresi variabel atmosfer sebesar 0,274 , jika variabel atmosfer dinaikkan 1 satuan sehingga dapat menaikan keputusan pembelian sebesar 0,274, dengan catatan variabel kualitas produk dan variabel brand image bernilai konstan (0) atau diabaikan.

3. b2 = Nilai koefisien regresi variabel kualitas produk sebesar 0,238 , artinya jika variabel kualitas produk dinaikkan 1 satuan maka akan menaikan keputusan pembelian sebesar 0,238 , dengan catatan variabel atmosfer dan variabel brand image bernilai konstan (0) atau diabaikan. 
4. b3 = Nilai koefisien regresi variabel brand image sebesar 0,366, artinya jika variabel brand image dinaikkan 1 satuan maka akan menaikan keputusan pembelian sebesar 0,366, dengan catatan variabel atmosfer dan variabel kualitas produk bernilai konstan (0) atau diabaikan.

5. Nilai koefisien regresi variabel brand image sebesar 0,366, merupakan nilai terbesar dibandingkan nilai koefisien regesi variabel atmosfer dan variabel kualitas produk, artinya keputusan pembelian sangat dipengaruhi oleh variabel brand image.

\section{Uji Asumsi Klasik}

a. Uji Normalitas

Tabel 3. Hasil Uji Normalitas

\begin{tabular}{lccl}
\hline & KS_Z & Sig. & Keterangan \\
& & & \\
\hline Unstandardized & 0,539 & 0,933 & Berdistribusi Normal
\end{tabular}

Dari hasil uji normalitas data tersebut nilai sig > 0,50, jadi kesimpulannya distribusi data penelitian ini dinyatakan berdistribusi normal.

b. Uji Multikolinearitas

Tabel 4. Hasil Uji Multikolinearitas

\begin{tabular}{llll} 
W & & & \\
\hline Variabel & TOL & VIF & Keterangan \\
\hline Atmosfer & 0,606 & 1,651 & Tidak terjadi multikolinearitas \\
Kualitas Produk & 0,832 & 1,202 & Tidak terjadi multikolinearitas \\
Brand Image & 0,686 & 1,458 & Tidak terjadi multikolinearitas \\
\hline
\end{tabular}

Dari hasil uji multikolinearitas didapat nilai Tolerance lebih dari 0,10 dan nilai VIF kurang dari 10, sehingga tidak terjadi multikolinearitas pada data penelitian ini.

c. Uji Heteroskedastisitas

Tabel 5. Hasil Uji Heteroskedastisitas

\begin{tabular}{lrll} 
刉 & \multicolumn{1}{c}{ thitung } & \multicolumn{1}{l}{ Sig. } & Keterangan \\
\hline Atmosfer & $-0,176$ & 0,861 Tidak ada heteroskedastisitas \\
Kualitas Produk & 0,116 & 0,908 Tidak ada heteroskedastisitas \\
Brand Image & $-1,478$ & 0,143 Tidak ada heteroskedastisitas \\
\hline
\end{tabular}

Hasil uji heteroskedastisitas dapat diketahui nilai $t_{\text {hitung }}<t_{\text {tabel }}$ dan nilai sig. Lebih dari 0,05 , sehingga tidak terjadi gejala heteroskedastisitas pada data penelitian ini.

\section{Uji Hipotesis}

a. Uji F

Tabel 6. Hasil Uji F

\begin{tabular}{cclc}
\hline \multicolumn{1}{c}{ Variabel } & $\mathrm{F}_{\text {hitung }}$ & Sig. & Keputusan \\
\hline $\begin{array}{l}\text { Atmosfer, kualitas produk } \\
\text { dan brand image }\end{array}$ & 23,859 & 0,000 & H0 ditolak \\
\hline
\end{tabular}


Temuan dari uji $\mathrm{F}$ didapat nilai sig. $0,000<0,05$, sehingga variabel atmosfer, kualitas produk, serta brand image berpengaruh terhadap keputusan pembelian konsumen secara simultan.

b. Uji t

Tabel 7. Hasil Uji t

\begin{tabular}{lccc}
\hline \multicolumn{1}{c}{ Variabel } & $\mathrm{t}_{\text {hitung }}$ & Sig. & Keputusan \\
\hline Atmosfer & 2,581 & 0,011 & H0 ditolak dan menerima Ha \\
Kualitas Produk & 2,679 & 0,009 & H0 ditolak dan menerima Ha \\
Brand Image & 3,763 & 0,000 & H0 ditolak dan menerima Ha \\
\hline
\end{tabular}

Temuan uji t tersebut diterangkan sebagai berikut :

a. Secara individual atmosfer dapat mempengaruhi keputusan pembelian

b. Secara individual kualitas produk dapat mempengaruhi keputusan pembelian

c. Secar individual brand image dapat mempengaruhi keputusan pembelian

\section{Pembahasan}

\section{Hubungan Atmosfer dan Keputusan Pembelian di Warung Apung Pondok Roso Klaten}

Berdasarkan hasil uji yang diperoleh dapat diterangkan bahwa atmosfer memiliki pengaruh secara signifikan terhadap keputusan pembelian. Hal ini menunjukkan bahwa konsumen dalam memilih tempat untuk makan akan mempertimbangkan atmosfer yang ditawarkan oleh warung makan. Dengan demikian maka konsumen akan mempertimbangkan atmosfer sebagai tempat makan yang nyaman dan tenang.. Hal ini sesuai dengan penelitian yang telah dilakukan oleh Cindy dan Rudy ( 2015 )

\section{Hubungan Kualitas Produk dan Keputusan Pembelian di Warung Apung Pondok Roso Klaten}

Berdasarkan hasil uji yang diperoleh dapat diterangkan bahwa variabel kualitas produk memiliki pengaruh positif pada keputusan pembelian. Hal ini dapat dibuktikan bahwa konsumen melakukan pembelian dengan pertimbangan kualitas makanan dan minuman yang disajikan oleh warung apung Pondok Roso. Warung apung Pondok Roso Rowo Jombor Klaten saat ini telah menambah variasi menu dengan rasa yang khas. Hal ini sesuai dengan penelitian Sarini ( 2013 )

\section{Hubungan Brand Image dan Keputusan Pembelian di Warung Apung Pondok Roso Klaten}

Berdasarkan hasil uji yang ditemuakan dapat diterangkan bahwa variabel brand image memiliki pengaruh yang positif dan signifikan pada keputusan pembelian. Hal ini dapat dibuktikan bahwa konsumen memilih tempat makan yang sudah memiliki citra nama yang baik dan sudah banyak di kenal oleh masyarakat luas. Warung Apung Pondok Roso telah dikenal banyak orang karena merupakan warung makan yang dirintis dari tahun 1968 sampai saat ini yang masih eksis ditengah banyaknya persaingan bisnis kuliner di Klaten.. Hal ini sesuai dengan penelitian yang telah dilakukan oleh Harianto dan Subagio ( 2013 ). 
Berdasarkan pemaparan yang telah diuraikan tersebut dapat diketahui bahwa variabel variabel dalam penelitian ini memiliki pengaruh yang baik dan signifikan pada keputusan pembelian.

\section{KESIMPULAN}

a. Temuan uji $\mathrm{F}$ menerangkan variabel atmosfer, kualitas produk, serta brand image secara bersama sama dan signifikan mempengaruhi keputusan pembelian konsumen di warung apung Pondok Roso Rowo Jombor Klaten.

b. Atmosfer memiliki pengaruh yang baik dan signifikan pada keputusan pembelian konsumen di warung apung Pondok Roso Rowo Jombor Klaten.

c. Kualitas produk memiliki pengaruh baik dan signifikan pada keputusan pembelian konsumen di warung apung Pondok Roso Rowo Jombor Klaten.

d. Brand Image memiliki positif dan signifikan terhadap keputusan pembelian konsumen di warung apung Pondok Roso Rowo Jombor Klaten.

\section{Saran}

1) Bagi Pihak Manajemen warung apung Pondok Roso Rowo Jombor Klaten

a. Mempertahankan atmosfer yang baik, kualitas produk, dan brand image, karena terbukti nyata bahwa antara atmosfer, kualitas produk, dan brand image memiliki pengaruh positif pada keputusan pembelian konsumen.

b. Meningkatkan atmosfer warung apung yang baik, karena variabel atmosfer adalah variabel pengaruhnya paling kecil diantara variabel lain pada keputusan pembelian, sehingga ke depannya konsumen warung apung Pondok Roso Rowo Jombor Klaten dapat lebih nyaman lagi di tempat makan dan dapat meningkatkan keputusan pembelian.

2) Bagi Peneliti Selanjutnya

a. Menambahkan variabel independent seperti: promosi, lokasi, variasi menu, harga, kualitas pelayanan dan lain-lain, sehingga lebih mampu memprediksi keputusan pembelian konsumen.

b. Menambahkan metode wawancara, sehingga data penelitian lebih lengkah dan akhirnya hasilnya juga lebih baik.

\section{DAFTAR PUSTAKA}

Aaker, D. (1991). Managing Brand Equity. New York: The Free Press

Gaman dan Sherrington ( 1996 ). The Science of food ( 4th ed ) oxford butterworth heinemann.

Ghozali, Imam. 2011. Aplikasi Analisis Multivariate Dengan Program SPSS. Edisi 5, Semarang: BP Universitas Diponegoro.

Gozali, Yolanda Widita et al. Analisa Pengaruh Faktor Kualitas Makanan, Kualitas Layanan, Dan Mood Terhadap Pemberian Tip Di Duck King Restoran Galaxy Mall Surabaya. Jurnal Hospitality dan Manajemen Jasa, Vol 4. No 1 (2016) 
Harianto David, Subagio Hartono. 2013. Analisa Pengaruh Kualitas Layanan, Brand Image, dan Atmosfer terhadap loyalitas konsumen dengan Kepuasan Konsumen sebagai variabel intervening konsumen keda Deja-Vu. Jurnal Manajemen Pemasaran, Vol. 1, No. 1, (2013) $1-8$

Kodu, Sarini. 2013. Harga, Kualitas Produk dan Kualitas Pelayanan Pengaruhnya Terhadap Keputusan Pembelian Mobil Toyota Avanza. Jurnal EMBA. ISSN : 2303-1174, Volume 1, No 3, September (2013).

Kotler, Philip. 2002. Manajemen Pemasaran. Jakarta: PT. Prenhalindo.

Kotler, plhilip \& amstrong, gary. Principle Of Marketing. (pearson prentice hall, 2014).

Margaretha, Japarianto Edwin. 2012. Analisa Pengaruh Food Quality dan Brand Image Terhadap Keputusan Pembelian Roti Kecik Toko Roti Ganep’s di Kota Solo. Jurusan Manajemen Pemasaran, Vol. 1, No. 1, ( 2012 ) 1 - 6.

Maryam, Siti. 2012. Statistik Induktif. Surakarta: Universitas Islam Batik Surakarta Press (UNIBA Press)

Musay Fransisca Paramitasari.2014. Pengaruh Brand Image Terhadap Keputusan Pembelian Survei Pada Konsumen KFC Kawi Malang.

Keller, K. L. (1993). Conceptualizing, Measuring, and Managing Customer-Based Brand Equity. Journal of Marketing, Vol.57, 1 - 22.

Sengkey, Cindy \& Wenas, Rudy. 2015. Analisis Citra Merek, Atmosfer Toko, dan Psikologis Terhadap Keputusan Pembelian pada Time Out Sport Cafe It Center Manado. Jurnal EMBA. ISSN : 2502 7689, Volume 3, No 1, Maret (2015).

Sugiyono, 2014. Metode Penelitian Kuantitatif. Bandung: Alfabeta

Tjiptono, Fandy \& Chandra, Gregorius. Pemasaran Strategik. (Andi Offset, 2011).

Tjiptono, Fandy \& Chandra, Gregorius. Pemasaran Strategik. (Andi Offset, 2012).

Utami, C. W. 2010. Manajemen ritel : Strategi dan Implementasi Opersional Bisnis Ritel Modern di Indonesia. Edisi 2, Salemba Empat, Jakarta

West, W., dan Hanger. 2007. Advertising \& Promotion: an IMC Perspective.8. 